KULTURA I WARTOŚCI

ISSN 2299-7806

NR 13/ 2015

ARTYKULY, s. 153-170

\title{
POCZATTKI FILOZOFII COHENA A PROBLEM PSYCHOLOGII
}

\begin{abstract}
Andrzej J. Noras
Hermann Cohen, twórca neokantowskiej szkoły marburskiej, jest uznawany za jednego z najbardziej radykalnych reprezentantów antypsychologizmu. Okazuje się jednak, że stanowisko to jest rezultatem procesu, w którym ujawniają się trzy ważne elementy, a mianowicie spór o psychologię, spór o Platona i spór o Kanta. W pierwszym wypadku Cohen okazuje się związany $\mathrm{z}$ psychologicznie zorientowanymi językoznawcami, a mianowicie Heymannem Steinthalem i Moritzem Lazarusem. W drugim wypadku Cohen okazuje się interpretatorem Platona, przy czym początkowo ujmuje go w duchu psychologizmu, od którego się później dystansuje. I wreszcie, w trzecim wypadku, z tego wynika późniejszy obraz filozofii Kanta.
\end{abstract}

Słowa kluczowe: Cohen, Steinthal, Lazarus, Platon, Kant

W historii filozofii Marburg traktowany jest jako ostoja naukowej filozofii, a szkoła marburska kojarzy się z radykalnie antypsychologiczną interpretacją Kanta. Teza ta jednak, nic nie tracąc ze swej aktualności, nie dotyczy początków filozofii, co wiąże się z kształtowaniem się filozoficznej drogi Cohena, który nie studiował pod kierunkiem żadnego wybitnego znawcy Kanta, a do jego nauczycieli należeli raczej przeciwnicy myśliciela $\mathrm{z}$ Królewca. Chodzi przede wszystkim o Friedricha Adolfa Trendelenburga (1802-1872), który zresztą w Berlinie przyjmował Cohena w poczet studentów. Okazuje się jednak, że proces dojrzewania Cohena do zajęcia się Kantem w duchu idealizmu krytycznego był procesem o charakterze ewolucyjnym i wiódł od Platona, zinterpretowanego w duchu psychologizmu, do krytyki nauki o

ANDRZEJ J. NORAS, profesor doktor habilitowany; Instytut Filozofii Uniwersytetu Śląskiego, Katowice, Polska; adres do korespondencji: ul. Bankowa 11, 40-007 Katowice. E-mail: andrzej.noras@us.edu.pl 
Kancie w takim kształcie, w jaki przedstawiają ją najwybitniejsi w tamtym czasie filozofowie, a mianowicie Kuno Fischer (1824-1907) oraz Trendelenburg. Przy czym, nie można nawet stwierdzić, że są to „znawcy Kanta”, bo jeśli teza ta jest prawdziwa w odniesieniu do Fischera, to $\mathrm{w}$ żadnym razie nie można tego powiedzieć o Trendelenburgu. Ten ostatni odwraca się bowiem od Królewieckiego myśliciela i kieruje się $\mathrm{w}$ stronę Arystotelesa, co jego biograf Ernst Bratuscheck (1837-1883) kwituje następująco: „Badanie Arystotelesa, czego przykład dał mu Brandis, zawsze zdawało mu się czymś więcej niż zadaniem życia"1.

Problem wynika $\mathrm{z}$ naukowej drogi Hermanna Cohena, rozpoczętej we Wrocławiu - gdy w roku 1857 podejmuje naukę w Żydowskim Seminarium Teologicznym (Das Jüdisch-theologische Seminar Fränckelsche Stiftung zu Breslau), którą przerywa w roku 1861 i przenosi się na Uniwersytet Wrocławski, gdzie studiuje filozofię i filologię klasyczną. W 1864 roku przenosi się do Berlina, gdzie - jak wspomniano - jest Trendelenburg, ale znawca Arystotelesa nie robi na nim większego wrażenia. Uczonym, którego wpływ na młodego Cohena był największy, był Heymann Steinthal (1823-1899), językoznawca i filozof, który wspólnie z Moritzem (wł. Mosesem) Lazarusem (18241903) wydawał czasopismo „Zeitschrift für Völkerpsychologie und Sprachwissenschaft". Czasopismo ukazywało się pod tym tytułem w latach 1859-1890 (dwadzieścia tomów), natomiast w latach 1891-1928 jako „Zeitschrift des Vereins für Volkskunde”. Redaktorem naczelnym był najpierw pochodzący z Dzierżoniowa Karl Weinhold (1823-1901), następnie Johannes Bolte (1858-1937), Hermann Michel (1877-1946) i wreszcie Fritz Boehm (1880-1943). Właśnie na łamach tego czasopisma debiutuje Cohen.

Moritz Lazarus², szwagier Steinthala, urodził się 15 września 1824 roku w miasteczku Wieleń (Filehne), a zmarł 13 kwietnia 1903 roku we Włoszech. Lazarus studiował w Berlinie, gdzie słuchał wykładów takich uczonych, jak Johannes Müller (1801-1858), Karl Wilhelm Ludwig Heyse (1797-1855) czy też Karl Ludwig Michelet (1801-1893). Heyse, ojciec poety Paula Heysego (1830-1914), laureata Nagrody Nobla w dziedzinie literatury (1910), zainteresował Lazarusa psychologią w ujęciu Herbarta; zainteresowanie to przejął również Steinthal. W roku

\footnotetext{
${ }^{1}$ E. Bratuscheck, Adolf Trendelenburg, Henschel, Berlin 1873, s. 49.

${ }^{2} \mathrm{Na}$ temat życia Lazarusa zob. Th. Achelis, Moritz Lazarus, Book on Demand, Hamburg 1900 oraz A. Leicht, Moritz Lazarus (15. September 1824 - 13. April 1903), Mittler, Berlin 1908 .
} 
1859 Lazarus został powołany do Berna, za sprawą rozprawy Das Leben der Seele, której pierwszy tom ukazał się w roku 1856, drugi w 1857, a trzeci dopiero w 1880. W roku 1867 Lazarusa powołano do Berlina do Preußische Kriegsakademie, zaś w roku 1873 został profesorem Uniwersytetu Berlińskiego - 1 czerwca tego roku został powołany jako pierwszy niemiecki profesor pochodzenia żydowskiego ${ }^{3}$. Problem w tym, że został powołany jako profesor honorowy, co powoduje, że dopiero Hermann Cohen uchodzi za pierwszego profesora pochodzenia żydowskiego.

Bezpośredni wpływ Steinthala - oraz pośredni Lazarusa - na myślenia Cohena jest wyraźny $\mathrm{w}$ tezach jego rozprawy doktorskiej, w których na plan pierwszy wysuwa się - zresztą w porządku chronologicznym również pierwsza - teza brzmiąca następująco: „Wszelki postęp filozofii jest ugruntowany w psychologii”. W ten sposób już na początku swej drogi filozoficznej Cohen niejako równocześnie znajduje się $\mathrm{w}$ centrum ówczesnych sporów. Są to mianowicie: (1) spór o psychologię, (2) spór o Platona i wreszcie (3) spór o Kanta. Stąd wynika też struktura niniejszego artykułu.

\section{I}

Faktem jest, że Steinthal jest dziś postacią zapomnianą, gdy tymczasem swego czasu był jednym $z$ czołowych językoznawców. W połowie dziewiętnastego wieku Steinthal odwołuje się do Wilhelma von Humboldta (1767-1835), który jako jeden z pierwszych miał się posłużyć terminem Völkerpsychologie. U Eislera znajduje się informacja, że początki nauki można znaleźć u dawnych psychologów, etnologów i socjologów - pojawiają się takie nazwiska jak Montesquieu czy Vico ${ }^{5}$ ale twórcami nauki są Lazarus i Steinthal. Klaus Christian Köhnke (1953-2013) wskazuje przede wszystkim na Moritza Lazarusa i wydany przez siebie zbiór jego tekstów poświęconych problemowi Völkerpsychologie ${ }^{6}$. Są tam zamieszczone teksty dotyczące właśnie Völkerpsychologie, nowej, powstającej $\mathrm{w}$ tamtym czasie psychologii.

\footnotetext{
${ }^{3}$ Zob. A. Leicht, Moritz Lazarus..., dz. cyt., s. 13.

${ }^{4}$ „Omnem philosophiae progressum in psychologia constitutum esse”. H. Cohen, Philosophorum de antinomia necessitatis et contingentia doctrinae, particula I, Hermann, Halae 1865, s. 36.

${ }^{5}$ Zob. R. Eisler, Wörterbuch der philosophischen Begriffe, 3, Aufl. t. 3, SCI-Z, Berlin 1910, 1678.

${ }^{6}$ M. Lazarus, Grundzüge der Völkerpsychologie und Kulturwissenschaft, red. K. Ch. Köhnke, Meiner, Hamburg 2003.
} 
Pierwszy z nich został opublikowany w roku $1851 \mathrm{w}$ wydawanym przez Roberta Prutza i Wilhelma Wolfsohna czasopiśmie „Deutsches Museum" i poświęcony był właśnie zagadnieniu pojęcia i możliwości nowej nauki, którą Lazarus nazywa Völkerpsychologie. Warto przy okazji zwrócić uwagę, że na język polski chyba najlepiej termin ten można przetłumaczyć jako „psychologia społeczna”, w każdym razie w żadnym wypadku nie można go tłumaczyć jako „psychologia ludowa”" . Lazarus więc w roku 1851 tak zaczyna swój tekst: „Podaliśmy nazwę nauki, która jako taka jeszcze nie istnieje" ${ }^{8}$ - co oznacza, że w zasadzie odwołać się trzeba do tych, którzy przyczynili się do rozwoju psychologii.

Pozostałe trzy teksty ukazały się na łamach „Zeitschrift für Völkerpsychologie und Sprachwissenschaft", wydawanego przez Lazarusa wraz ze Steinthalem. W roku 1862 ukazały się dwa teksty, a mianowicie Verdichtung des Denkens in der Geschichte oraz Ueber das Verhältniß des Einzelnen zur Gesammtheit ${ }^{10}$. Ostatni artykuł jest tekstem wykładu, jaki Lazarus wygłosił w Bernie 11 stycznia 1861 roku. Wreszcie w roku 1865, w trzecim tomie wydawanego wspólnie ze Steinthalem czasopisma zamieścił Lazarus obszerny tekst poświęcony zagadnieniu psychologii społecznej - Einige synthetische Gedanken zur Völkerpsychologie ${ }^{11}$.

O ile Lazarus stworzył pojęcie Völkerpsychologie, o tyle Steinthal odwołuje się do Wilhelma von Humboldta, którego zresztą teksty wydaje $^{12}$. Przejmuje od niego tezę, że myślenie jest uwarunkowane przez język, a zatem światopogląd ma swe uzasadnienie społeczne. Dlatego też termin można tłumaczyć jako „psychologia społeczna”, z zastrzeżeniem, że idzie o dyscyplinę, która łączy w sobie elementy etnologii i socjologii kultury, a zatem w pewnym sensie idzie o „antropologię kulturową”,

\footnotetext{
${ }^{7}$ Tenże, Ueber den Begriff und die Möglichkeit einer Völkerpsychologie, „Deutsches Museum. Zeitschrift für Literatur, Kunst und öffentliches Leben" 1851, red. R. Prutz, W. Wolfsohn, rocz. 1, s. 112-126.

${ }^{8}$ Tamże, s. 112 .

${ }^{9}$ Tenże, Verdichtung des Denkens in der Geschichte. Ein Fragment, „Zeitschrift für Vö1kerpsychologie und Sprachwissenschaft" 1862, t. 2, F. Dümmler, s. 54-62.

${ }^{10}$ Tenże, Ueber das Verhältniß des Einzelnen zur Gesammtheit, ,Zeitschrift für Völkerpsychologie und Sprachwissenschaft" 1862, t. 2, F. Dümmler, s. 393-453. Przedrukowane w: Idem, Das Leben der Seele in Monographieen über seine Erscheiningen und Gesetze, 2, Aufl. t. 1, Berlin 1876, s. 323-411.

${ }^{11}$ Tenże, Einige synthetische Gedanken zur Völkerpsychologie, „Zeitschrift für Völkerpsychologie und Sprachwissenschaft" 1865, t. 3, F. Dümmler, s. 1-94.

${ }^{12}$ Die sprachphilosophischen Werke Wilhelm's von Humboldt, red. H. Steinthal, F. Dümmler, Berlin 1883-1884.
} 
chociaż reprezentanci tej ostatniej nie odwołują się ani do Humboldta widząc $\mathrm{w}$ nim jedynie twórcę językoznawstwa porównawczego - ani tym bardziej do Steinthala, który z tej perspektywy w ogóle pozostaje nieznany. $Z$ dzisiejszego punktu widzenia ważne jest jednak również to, że psychologia Steinthala odwołuje się do psychologii Johanna Friedricha Herbarta (1776-1841).

Dodać zresztą trzeba, że pierwsza książka Steinthala poświęcona została porównaniu filozofii języka Humboldta $\mathrm{z}$ metodą filozofii $\mathrm{Hegla}^{13}$. Książka jest także niezwykle interesująca $\mathrm{z}$ perspektywy doktryny późnego Cohena, ten bowiem będzie nawiązywał do Steinthala, który w odniesieniu do Hegla pyta: „Czymże więc jest czyste myślenie?”14 i odpowiada: „Czyste myślenie pojmuje się (zestawia się) samo w sobie samym" ${ }^{15}$. Steinthal odwołuje się przede wszystkim do teorii języka Wilhelma von Humboldta, chociaż nie pozostaje obojętny również na wpływy innych filologów i - podobnie jak Lazarus odwołuje się do Heysego. Zaletą jego stanowiska jest postrzeganie języka w szerokim kontekście: „Język jest tylko częścią całego kompleksu przejawów życia ducha narodu i czasu, zaś jego czysto filologiczne rozważanie może mieć za przedmiot tylko jego historyczny rozwój w obrębie granic określonej epoki i to w stałym związku z pozostałymi manifestacjami duchowego życia narodu"16. Za najważniejsze dzieło Humboldta uznaje Steinthal trzytomowe opracowanie poświęcone historycznemu językowi „kawi”, który był literackim językiem opartym na starojawajskiej gramatyce ${ }^{17}$. Steinthal podkreśla, że „zasadą wszelkiej historii jest zatem według Humboldta duchowa siła"18, zaś sam Humboldt stwierdza: „Istnieją więc w procesie rozwoju rodzaju ludzkiego postępy, które zostają osiągnięte dlatego, że jakaś niezwyczajna siła nieoczekiwanie wznosi się tam, gdzie w miejsce

\footnotetext{
${ }^{13}$ W. Steinthal, Die Sprachwissenschaft Wilh. v. Humboldt's und die Hegel'sche Philosophie, Heymann, Berlin 1848

${ }^{14}$ Tamże, s. 3.

15 „Das reine Denken begreift (fasst zusammen) sich mit sich in sich selbst”. Tamże, s. 6.

${ }^{16}$ Tamże, s. 33.

${ }^{17}$ W. von Humboldt, Über die Kawi-Sprache auf der Insel Java, nebst einer Einleitung über die Verschiedenheit des menschlichen Sprachbaues und ihren Einfluss auf die geistige Entwickelung des Menschengeschlechts, t. 3, Druckerei der Königlichen Akademie der Wissenschaften, Berlin 1836-1838-1839.

${ }^{18}$ W. Steinthal, Die Sprachwissenschaft Wilh. v. Humboldt's und die Hegel'sche Philosophie..., dz. cyt. s. 39 .
} 
zwyczajowego wyjaśnienia wytworzonego działania trzeba przyjąć wypadki odpowiadającej jej przejawu siły"19.

\section{II}

Zatem już pierwsza konstatacja wydaje się zaskakująca: punkt wyjścia filozofii Cohena stanowi psychologia, co jest niezwykle ważne w świetle jego późniejszych poczynań. Można rzec paradoksalnie, że sytuacja przedstawia się następująco: punkt wyjścia Cohena jest uwarunkowany psychologicznie, zaś z dzisiejszej perspektywy całość filozofii Cohena postrzegana jest jako wyraz radykalnego antypsychologizmu. Czyżby więc $\mathrm{w}$ późniejszym etapie swej twórczości Cohen spłacał dług wobec filozofii, dystansując się od psychologicznego punktu wyjścia? Dość powiedzieć, na co zwraca uwagę Köhnke ${ }^{20}$, że między rokiem 1886 a 1869 Cohen opublikował trzy psychologiczne rozprawy w czasopiśmie Steinthala i Lazarusa. Jako pierwszy, w roku 1866 został opublikowany artykuł poświęcony Platonowi - Die platonische Ideenlehre, psychologisch entwickelt $^{21}$. To zresztą wzmaga aurę tajemniczości wokół filozofii Cohena. Znany neokantysta, twórca szkoły marburskiej nie rozpoczyna od Kanta, ale od Platona i to interpretowanego w sposób psychologiczny. W następnym tomie - sygnowanym datą 1868 - Cohen zamieścił tekst Mythologische Vorstellungen von Gott und Seele psychologisch entwickelt ${ }^{22}$, którego część druga ukazała się $\mathrm{w}$ następnym tomie, opublikowanym rok później ${ }^{23}$. W tym samym tomie ukazał się trzeci tekst, poświęcony poetyckiej fantazji i mechanizmowi świadomości ${ }^{24}$. Co interesujące, już w tytule tekstu pojawia się pojęcie „mechanizmu świadomości”, który to mechanizm świadomości - jak zauważa Köhnke

\footnotetext{
${ }^{19}$ W. von Humboldt, Über die Kawi-Sprache auf der Insel Java..., t. 1, dz. cyt., s. XXXII.

${ }^{20}$ K. Ch. Köhnke, „Unser junger Freund”. Hermann Cohen und die Völkerpsychologie, [w:] Hermann Cohen und die Erkenntnistheorie, red. W. Marx und E. W. Orth, Königshausen u. Neumann, Würzburg 2001, s. 62.

${ }^{21} \mathrm{H}$. Cohen, Die platonische Ideenlehre, psychologisch entwickelt, „Zeitschrift für Vö1kerpsychologie und Sprachwissenschaft" 1866, t. 4, F. Dümmler, s. 403-464.

${ }^{22}$ Tenże, Mythologische Vorstellungen von Gott und Seele psychologisch entwickelt, „Zeitschrift für Völkerpsychologie und Sprachwissenschaft" 1868, t. 5, F. Dümmler, s. 396434.

${ }^{23}$ Tenże, Mythologische Vorstellungen von Gott und Seele psychologisch entwickelt II, „Zeitschrift für Völkerpsychologie und Sprachwissenschaft" 1869, t. 6, F. Dümmler, s. 113131.

${ }^{24}$ Tenże, Die dichterische Phantasie und der Mechanismus des Bewußtseins, „Zeitschrift für Völkerpsychologie und Sprachwissenschaft” 1869, t. 6, F. Dümmler, s. 173-263.
} 
- „Cohen rozumie dosłownie jako mechanikę ducha, co jednak nie ma nic do czynienia z psychologią społeczną" ${ }^{25}$. Najważniejsze są tu dwie rzeczy, a mianowicie połączenie Platona $z$ psychologią. Oczywiście stanowisko to $\mathrm{w}$ rozwoju filozofii marburskiej zostało zweryfikowane na rzecz antypsychologizmu, niemniej jednak punkt wyjścia jest istotny. Niezwykle zwięźle i trafnie zarazem stanowisko Cohena ocenia KarlHeinz Lembeck: „W swoich berlińskich czasach Cohen pozostaje pod wpływem psychologów społecznych i językoznawców Heymanna Steinthala i Moritz Lazarusa. Za ich pośrednictwem poznał matematyczną psychologię Herbarta. Ta tradycja wpływa jeszcze na jego pierwszą książkę o Kancie z roku 1871. A także jego rozumienie Platona wynika z tych źródeł"26.

Już pierwsze słowa artykułu z roku 1866 przedstawiają się niezwykle intrygująco: „Platońska teoria idei jest odkryciem. Odkryciem nazywam takie rozszerzenie świadomości naukowej, które za pomocą znaczącej apriorycznej kombinacji przekształca aposterioryczny materiał wiedzy, i udostępnia nowe drogi badania. Ponieważ nie tylko na tym polega istota odkrycia, że bezpośrednio wydobywa skarb prawdy, lecz zarazem i najczęściej na tym, że otwiera nowe owocne źródła poznania. Oba warunki są spełnione w Platońskiej teorii idei" ${ }^{27}$. Jednakże, już na wstępie podkreśla Cohen, że każde odkrycie jest „procesem

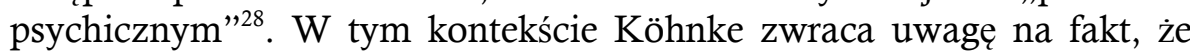
każdą teorię musi ując jako proces psychiczny. „Zatem pierwszy warunek dla historyka filozofii musi być taki, że każdą teorię, którą musi uznać za odkrycie, musi odkryć (nachentdecken) w jej własnych, ale ogólnoludzkich, apriorycznych elementach, i rozwinać oraz przedstawić jako proces psychiczny zgodny z psychicznymi prawami" ${ }^{29}$. W takim razie widać wyraźnie, że $\mathrm{w}$ roku 1866 Cohen pojmuje teorię idei przede wszystkim psychologicznie, aczkolwiek nie brak tu elementów metodologicznych ${ }^{30}$. Cohen zadaje pytanie: „Czym jest platońska idea?

\footnotetext{
${ }^{25}$ K. Ch. Köhnke, „Unser junger Freund”. Hermann Cohen und die Völkerpsychologie..., dz. cyt., s. 62 .

${ }^{26}$ K.-H. Lembeck, Platon in Marburg. Platonrezeption und Philosophiegeschichtsphilosophie bei Cohen und Natorp, Königshausen u. Neumann, Würzburg 1994, s. 22.

${ }^{27}$ H. Cohen: Die platonische Ideenlehre, psychologisch entwickelt..., dz. cyt., s. 403.

${ }^{28}$ Tamże.

${ }^{29}$ Tamże, s. 404. Por. K. Ch. Köhnke, „Unser junger Freund”. Hermann Cohen und die Völkerpsychologie..., dz. cyt., s. 66.

${ }^{30}$ Zwraca na to uwagę Karl-Heinz Lembeck. Zob. K.-H. Lembeck, Platon in Marburg..., dz. cyt., s. 25 .
} 
W jakim procesie psychicznym powstała?"31. Przy okazji - co jest niezwykle istotne dla późniejszego rozumienia filozofii marburskiej - już tutaj Cohen znajduje istotny związek pomiędzy Platonem a Kantem i przytacza ogromny fragment tekstu $z$ początkowych rozważań dialektyki transcendentalnej. Warto ten fragment przywołać, gdyż zdaje się on mieć kluczowe znaczenie dla późniejszych działań Cohena:

„»Nie chcę się tutaj zapuszczać w żadne badania literackie, by wynaleźć sens, który ów wzniosły filozof wiązał ze swym wyrazem. Zaznaczam tylko, że nie jest niczym niezwykłym, zarówno w prostej rozmowie, jak i w pismach, dzięki porównywaniu myśli, które pewien autor wypowiada o swym przedmiocie, rozumieć go nawet lepiej, niż on sam siebie rozumiał, nie określiwszy dostatecznie swego pojęcia i wskutek tego czasami mówiąc, a także myśląc coś wbrew własnej intencji. Platon $\mathrm{z}$ pewnością trafnie zauważył, że nasza władza poznawcza odczuwa znacznie wyższe potrzeby niż samo sylabizowanie zjawisk wedle jedności syntetycznej, by je móc odczytać jako doświadczenie, i że nasz rozum $\mathrm{w}$ sposób naturalny wznosi się do poznań, które sięgają o wiele za daleko na to, żeby jakikolwiek przedmiot, o którym może nas pouczyć doświadczenie, mógł się kiedykolwiek z nimi dokładnie zgadzać. Ale mimo to mają one swoją realność i nie są wcale urojeniami«. Ponadto w przypisie zauważa: »Rozciągnął on, co prawda, swe pojęcie także na poznania spekulatywne, o ile tylko były dane w sposób czysty i całkowicie a priori, a nawet na matematykę, choć przedmioty jej nie są dane gdzie indziej, jak tylko w możliwym doświadczeniu. W tym nie mogę pójść za nim, tak samo jak w mistycznej dedukcji tych idei lub w przesadzie, z jaką on je jakby hipostazował, choć szumne słowa, jakimi się na tym polu posługiwał, można złagodzić i bardziej dostosować do natury rzeczy«"32. Przytoczony fragment $z$ tekstu Kanta skłania Köhnkego do uznania, że Cohen znajduje się tu bliżej Fichtego niż Kanta, gdyż Fichte w Reden an die deutsche Nation odwołuje się do słów „rozumieć autora nawet lepiej, niż on sam siebie rozumiał" ${ }^{\prime 3}$.

\footnotetext{
${ }^{31}$ H. Cohen: Die platonische Ideenlehre, psychologisch entwickelt..., dz. cyt., s. 405.

${ }^{32}$ Tamże, s. 406-407. Por. I. Kant, Kritik der reinen Vernunft (1. Aufl.), [w:] tenże, Gesammelte Schriften, Kritik der reinen Vernunft (1. Aufl.), Prolegomena, Grundlegung zur Metaphysik der Sitten, Metaphysische Anfangsgründe der Naturwissenschaft, t. 4, C.A. Schwetschke und Sohn, Berlin 1903, s. 200. Wydanie polskie: I. Kant, Krytyka czystego rozumu, t. 2, tłum. R. Ingarden, PWN, Warszawa 1957, s. 23-24.

${ }^{33}$ K. Ch. Köhnke, ,Unser junger Freund”. Hermann Cohen und die Völkerpsychologie..., dz. cyt., s. 66. Por. J. G. Fichte, Reden an die deutsche Nation, [w:] Sämmtliche Werke, red. von I. H. Fichte, t. 7, Berlin 1846, s. 326.
} 
Zatem problem jest jeszcze bardziej złożony. Okazuje się bowiem, że początki związane są nie tylko $z$ psychologią społeczną i językoznawstwem w ujęciu Steinthala i Lazarusa, ale dodatkowo kluczową rolę odgrywa tu Platon i - jak się okazuje - Kant. Początki są jednak trudne - chciałoby się rzec, patrząc na punkt wyjścia Cohena, uwikłanego w psychologię społeczną i językoznawstwo. Uwikłanie to wynika $\mathrm{z}$ sytuacji, w jakiej znalazła się filozofia i dlatego istotnym elementem refleksji jest określenie relacji filozofii do nauk szczegółowych. Problem filozofii w czasach neokantyzmu trafnie charakteryzuje Christian Krijnen: „Pomimo swej nazwy neokantyzm nie zawdzięcza jej wyłącznie zwrotowi do filozofii Kantowskiej z zamiarem jej zdecydowanej kontynuacji. Neokantyzm miał raczej zarazem do wypełnienia zadanie polemiczne: musiał się wypowiedzieć przeciwko owym pozytywistycznym, scjentystycznym, historystycznym i wynikającym z filozofii życia tendencjom epoki, pod wpływem których idealizm pokantowski już wkrótce po śmierci Hegla stracił swą dominującą rolę w duchowym życiu Niemiec"34. Spośród dyscyplin, które w przekonaniu są ważne dla określenia miejsca filozofii, na plan pierwszy wysuwa się $\mathrm{u}$ Cohena psychologia. Nie jest przy tym oryginalny, gdyż rok wcześniej, niż Cohen opublikował pierwsze wydanie Kants Theorie der Erfahrung, Jürgen Bona Meyer opublikował książkę poświęconą psychologii Kanta ${ }^{35}$.

Teza o psychologicznym charakterze filozofii jest niezwykle doniosła również dla Natorpa, który w 1888 wydaje książkę poświęconą psychologii i - co uwyraźnia Ulrich Sieg - akcentuje jej deskryptywny charakter $^{36}$. Natorp podkreśla tam, że „nie istnieje żadna własna, niezależnie od przyrodoznawstwa ugruntowana teoria zjawisk psychicznych"37. Jest to o tyle ciekawe, że wpisuje się w poglądy Cohena, chociaż podlega również pewnej ewolucji i dlatego w roku 1912

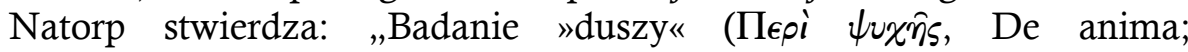
"psychologia" jest dopiero nowożytnym neologizmem) obejmuje wspólne fundamentalne założenia wszystkich nauk o przyrodzie

\footnotetext{
${ }^{34} \mathrm{Ch}$. Krijnen, Hegel und der Neukantianismus. Eine systemphilosophische Konfrontation, [w:] Hegel und die Geschichte der Philosophie, red. D. H. Heidemann, Ch. Krijnen, Wissenschaftliche Buchgesellschaft, Darmstadt 2007, s. 240.

${ }^{35}$ J. B. Meyer, Kant's Psychologie, Hertz, Berlin 1870.

${ }^{36}$ Zob. U. Sieg, Aufstieg und Niedergang des Marburger Neukantianismus. Die Geschichte einer philosophischen Schulgemeinschaft, Königshausen u. Neumann, Würzburg 1994, s. 169.

${ }^{37}$ P. Natorp, Einleitung in die Psychologie nach kritischer Methode, Mohr, Freiburg i.B. 1888, s. 62 (§ 10).
} 
ożywionej, a więc prawa życia roślinnego w nie mniejszym stopniu niż życia zwierzęcego i ludzkiego" 38 .

Hermann Cohen wpisuje się więc w charakterystyczną w latach siedemdziesiątych i osiemdziesiątych dziewiętnastego stulecia dyskusję nad statusem psychologii, a stanowisko zajęte $\mathrm{w}$ tym sporze dalekie jest od tego, które uznaje się za charakterystyczne dla szkoły marburskiej. Słusznie zatem Winrich de Schmidt mówi o „młodym i przedkrytycznym Cohenie jako uczniu Steinthala" ${ }^{39}$, który przejmuje od swojego nauczyciela pojęcia filozofii i psychologii. Interesujące zdaje się być to, że w zasadzie nie można mówić inaczej o filozofii Steinthala, jak tylko jako o kantyzmie ${ }^{40}$, co nie zmienia jego uwikłania w spór o psychologię. Co ciekawe, Cohen mówi o mechanizmie świadomości, choć pojawia się tu pojęcie ,jedność świadomości”"11, którego będzie używał później. Zresztą terminu „mechanizm świadomości” nie należy rozumieć w sposób mechanistyczny. Chodzi Cohenowi raczej o determinizm tworzenia przedstawieńn ${ }^{42}$. Nie zmienia to jednak faktu, że kluczowe jest tu psychologiczne nastawienie wyrażające się w przekonaniu, że filozofia powinna badać procesy psychiczne ${ }^{43}$.

\section{III}

Przekonanie o psychicznym charakterze procesów świadomościowych towarzyszy Cohenowi także podczas pisania Kants Theorie der Erfahrung i - jak zwraca na to uwagę de Schmidt - właśnie pod tym względem wydanie $\mathrm{z}$ roku $1871^{44}$ różni się od wydania drugiego, z roku $1885^{45}$. Nie chodzi tylko o objętość dzieła, chociaż i tu różnica jest znaczna, gdyż w pierwszym wydaniu książka liczyła 270 stron, natomiast $\mathrm{w}$ drugim już 616. Idzie raczej o zmianę sposobu uzasadniania aprioryczności, a sam Cohen podkreśla to w przedmowie do wydania drugiego, wskazując na książkę, która ukazała się dwa lata

\footnotetext{
${ }^{38}$ Tenże, Allgemeine Psychologie nach kritischer Methode, Mohr, Tübingen 1912, s. 4.

${ }^{39}$ W. de Schmidt, Psychologie und Transzendentalphilosophie. Zur Psychologie-Rezeption bei Hermann Cohen und Paul Natorp, Bouvier, Bonn 1976, s. 19-34.

${ }^{40}$ Zob. tamże, s. 25.

${ }^{41}$ Zob. H. Cohen, Die dichterische Phantasie und der Mechanismus des Bewußtseins..., dz. cyt., s. 199.

${ }^{42}$ Zob. tamże, s. 201.

${ }^{43}$ Zob. W. de Schmidt, Psychologie und Transzendentalphilosophie..., dz. cyt., s. 31.

${ }^{44} \mathrm{H}$. Cohen, Kants Theorie der Erfahrung, Dümmler, Berlin 1871.

${ }^{45}$ Tenże, Kants Theorie der Erfahrung, t. 2, neubearbeitete Aufl., Dümmlers Verlagsbuchhandlung, Harrwitz und Gossmann, Berlin 1885.
} 
wcześnie i już w podtytule przynosi pojęcie krytyki poznania ${ }^{46}$. Dodatkowo można tu jeszcze wskazać dwa inne ważne teksty, a mianowicie wydaną $\mathrm{w}$ roku 1877 książkę poświęconą ugruntowaniu etyki $^{47}$ oraz nowy tekst o Platonie ${ }^{48}$. Przy czym sprawa się znowu komplikuje, bo $\mathrm{w}$ gruncie rzeczy krytyka psychologizmu wiąże się z pojęciem „uświadomienia” (Bewusstheit), które Cohen odróżnia od świadomości (Bewusstsein) właśnie w celu uniknięcia podejrzenia o psychologizm. Po raz pierwszy terminu „uświadomienie” Cohen użył w Kants Begründung der Ethik ${ }^{49}$, a następnie w Das Princip der InfinitesimalMethode, gdzie mówi o tym, że uświadomienie oznacza „możliwość świadomości naturalnej" ${ }^{50}$. Pojęcie uświadomienia - to swoisty paradoks - pojawia się również u Steinthala, który opisuje istotę uświadomienia we Wprowadzeniu do psychologii, ale dopiero $\mathrm{w}$ drugim wydaniu termin ten pojawia się $\mathrm{w}$ spisie treści ${ }^{51}$, gdyż $\mathrm{w}$ wydaniu pierwszym, które ukazało się w tym samym roku, co pierwsze wydanie Kants Theorie der Erfahrung Cohena, pojęcie uświadomienia nie pojawia się w spisie treści, choć w książce występuje ${ }^{52}$. Zatem może być również tak, że występujące u Cohena w Kants Begründung der Ethik pojęcie uświadomienia ma swoje źródło w koncepcji Steinthala.

Geert Edel w recenzji książki Schmidta podkreśla, że autorowi udało się pokazać Cohena „przeciwstawiającego się psychologizującym tendencjom interpretacji Kanta" ${ }^{, 53}$. Nie jest to Kant pojęty w duchu psychologizmu, ale - zdaniem Edela - w duchu mającego się ujawnić antypsychologizmu, co z pewnością nie do końca odpowiada prawdzie. Ujęcie Kanta dalekie jest od psychologizmu, chociaż elementy mogące świadczyć o psychologizującej interpretacji tu występują. Sam Schmidt podkreśla, że oprócz mechanizmu świadomości w doktrynie Cohena występują elementy zaczerpnięte wprost z psychologii Herbarta ${ }^{54}$, zaś na

\footnotetext{
${ }^{46}$ Tenże, Das Princip der Infinitesimal-Methode und seine Geschichte. Ein Kapitel zur Grundlegung der Erkenntnisskritik, Berlin 1883.

${ }^{47}$ Tenże, Kants Begründung der Ethik, Dümmler, Berlin 1877.

${ }^{48}$ Tenże, Platons Ideenlehre und die Mathematik, Marburg 1878.

${ }^{49}$ Tenże, Kants Begründung der Ethik, dz. cyt., s. 46.

${ }^{50}$ Tenże, Das Princip der Infinitesimal-Methode und seine Geschichte..., dz. cyt., s. 20. Na ten temat zob. A. J. Noras, Pojęcie samoświadomości w filozofii świadomości Paula Natorpa, „Folia Philosophica”, red. P. Łaciak, t. 32, Katowice 2014, s. 87-106.

${ }^{51}$ H. Steinthal, Einleitung in die Psychologie und Sprachwissenschaft, t. 2, Aufl, Berlin 1881 , s. $131-137$.

${ }_{52}$ Zob. H. Steinthal, Einleitung in die Psychologie und Sprachwissenschaft, Berlin 1871.

${ }^{53}$ G. Edel, Winrich de Schmidt: Psychologie und Transzendentalphilosophie, Bonn 1976, „Archiv für Geschichte der Philosophie” 1978, t. 60, Bouvier, s. 236-239, tu 237.

${ }^{54}$ Zob. W. de Schmidt: Psychologie und Transzendentalphilosophie..., dz. cyt., s. 36-37.
} 
plan pierwszy wysuwa się przekonanie o poznaniu rozumianym jako proces - to zaś jest charakterystyczne dla całej szkoły marburskiej. Co ciekawe, również dla Nicolaia Hartmanna, który również przez de Schmidta, choć $\mathrm{z}$ zastrzeżeniami, to jednak traktowany jest jako przeciwnik Cohena. Hartmann występuje tu oczywiście jako autor książki Grundzüge einer Metaphysik der Erkenntnis ${ }^{55}$. Problem ugruntowania aprioryczności budzi najwięcej wątpliwości w pierwszym wydaniu Kants Theorie der Erfahrung Cohena, co nie zmienia faktu, że rację ma de Schmidt, który zauważa: „Już pierwsza Kantowska książka Cohena kieruje się przeciwko psychologizującym i antropologizującym tendencjom interpretacji Kanta" ${ }^{, 56}$. W związku z tym nasuwa się pytanie, czy nie jest $\mathrm{w}$ istocie tak, że problemem Cohena jest subiektywizm, jak chce tego Oskar Ewald ${ }^{57}$, który wskazuje ponadto na Johannesa Volkelta, jako przeciwnika tegoż subiektywizmu? „Badacz ten - pisze o Cohenie Volkelt - wyciąga przedwczesny wniosek, kiedy myśli, że dlatego, iż Kantowskie a priori jako formalne uposażenie podmiotu "wytwarza«, »konstruuje« przedmioty, subiektywność przestrzeni musi być wyłączna (aufschliessende)" ${ }^{\prime 58}$. Zatem problem psychologii ukazuje się w świetle aprioryczności, a ściślej - jej ugruntowania, a problemem Cohena - przynajmniej w pierwszym wydaniu Kants Theorie der Erfahrung - jest odpowiedź na pytanie o to, jak w tym kontekście rozumieć subiektywność. „Przezwyciężenie fałszywej dysjunkcji subiektywny-obiektywny za pomocą pojęcia transcendentalnie subiektywnego jest ważnym osiągnięciem neokantowskiego filozofowania; o ile mi wiadomo Cohen jest pierwszym neokantystą, który poszukiwał przezwyciężenia tego przeciwieństwa i w dużej części także zrealizował" ${ }^{59}$.

\footnotetext{
${ }^{55}$ N. Hartmann, Grundzüge einer Metaphysik der Erkenntnis, t. 4, Aufl. Berlin 1949.

${ }^{56}$ W. de Schmidt, Psychologie und Transzendentalphilosophie..., dz. cyt., s. 66.

${ }^{57}$ Zob. O. Ewald, Kants Methodologie in ihren Grundzügen. Eine erkenntnistheoretische Untersuchung, Berlin 1906, s. 23-26.

58 „Dieser Kantforscher macht einen übereilten Schluss, wenn er meint, dass darum, weil das Kantische Apriori als formale Beschaffenheit des Subjectes die Objecte »erzeuge«, "construire«, die Subjectivität des Raumes eine ausschliessende sein müsse" J. Volkelt, Immanuel Kant's Erkenntnisstheorie nach ihren Grundprincipien analysiert. Ein Beitrag zur Grundlegung der Erkenntnisstheorie, Berlin 1879, s. 46.

${ }^{59}$ W. de Schmidt: Psychologie und Transzendentalphilosophie..., dz. cyt., s. 54.
} 
Nie wolno jednak, analizując problem ugruntowania a priori, a pośrednio problem miejsca psychologii w filozofii Cohena, zapomnieć o tekście z roku 1871, a więc $\mathrm{z}$ tego samego roku, w którym ukazało się pierwsze wydanie Kants Theorie der Erfahrung. Tekst również ukazał się na łamach czasopisma „Zeitschrift für Völkerpsychologie und Sprachwissenschaft" i był poświęcony dyskusji, jaka toczyła się o rozumienie Kanta pomiędzy Friedrichem Adolfem Trendelenburgiem a Kunonem Fischerem ${ }^{60}$. Spór toczony był w coraz gorętszej atmosferze i koncentrował się wokół faktu istnienia - bądź nieistnienia - luki w Kantowskim dowodzie subiektywności czasu i przestrzeni ${ }^{61}$. Cohen, przystępując do analiz, zwraca uwage na problem psychologii, potwierdzając jego aktualność i pisze: „Własne posuwanie się do przodu w myśleniu na wszystkich drogach musi brać swój początek od wyraźnej linii granicznej, którą Kant wyznaczył wszelkiej przyszłej metafizyce, a przez to wszelkiej psychologii. Ponieważ nieśmiałą rezygnację, którą współczesna empiryczna psychologia obserwuje w stosunku do metafizycznych pytań podstawowych, należałoby postrzegać nie jako tymczasowe metodyczne samoograniczenie na korzyść możliwie nieuprzedzonego zbioru faktów psychicznych, lecz jako ugruntowane $\mathrm{w}$ istocie rzeczy przeciwieństwo, jeśli chce się zaprzeczyć jedności wszelkiej psychologii $\mathrm{z}$ metafizyką ${ }^{\prime 2}$. Cohen podkreśla tu zatem odmienny stosunek do psychologii, który wyraża się nie tylko w uznaniu metafizyki i psychologii, lecz także w przedmiocie sporu, jakim jest estetyka transcendentalna, która w świetle późniejszego systemu filozofii nie ma już takiego znaczenia jak wcześniej.

Problem psychologii $\mathrm{W}$ artykule poświęconym rozumieniu Kantowskiego a priori wyraża się zatem w ujęciu obiektywności, bo przecież o nią tu chodzi. Trafnie spór charakteryzuje Krystyna Święcicka, która pisze: „Trendelenburg uważał, że możliwe jest połączenie przekonania o czystej subiektywności przestrzeni i czasu z równoczesnym uznaniem ich obiektywnego istnienia i że możliwość tę Kant przeoczył. Twierdził ponadto, że Kant w swoim dowodzie

\footnotetext{
${ }^{60} \mathrm{H}$. Cohen, Zur Controverse zwischen Trendelenburg und Kuno Fischer. „Zeitschrift für Völkerpsychologie und Sprachwissenschaft" 1871, t. 7, F. Dümmler, s. 249-296.

${ }^{61}$ Zob. A. J. Noras, Historia neokantyzmu, Katowice 2012, s. 124-153 oraz A. J. Noras, Debata Trendelenburg - Fischer. Problem obiektywności Kantowskich form zmystowości, „Przegląd Filozoficzny - Nowa Seria” 2013, r. 22, nr 1, s. 267-297.

${ }^{62}$ H. Cohen, Zur Controverse zwischen Trendelenburg und Kuno Fischer..., s. 250.
} 
wyłącznej (ausschliessende) subiektywności przestrzeni i czasu pozostawił lukę. Kuno Fischer natomiast starał się dowieść, że luka ta w Kantowskim dowodzie nie występuje"63.

Spór zdaje się mieć szczególne znaczenie dla recepcji filozofii Kanta $\mathrm{w}$ jakimś sensie kieruje uwagę filozofów na problem (resp. problemy), występujące w jego filozofii. Dyskusja między Trendelenburgiem a Fischerem jest wprawdzie wzorcowym przykładem takich sporów, ale nie jedynym. Takich sporów o to, jak rozumieć filozofię myśliciela z Królewca, toczono w tamtym czasie wiele. Konsekwencją jest coraz lepsze zrozumienie idealizmu transcendentalnego.

\section{V}

Hermann Cohen nie jest bynajmniej filozofem, który od samego początku ma jasny obraz filozofii Kanta. Tym wszakże, co go wyróżnia $z$ całej rzeszy badaczy, jest nieustanna ewolucja myślenia, dzięki której stosunkowo szybko uświadomił on sobie, że problem ugruntowania nauki (i filozofii) nie może się odwoływać do psychologii. Stało się to w roku 1883, kiedy w Das Princip der Infinitesimal-Methode und seine Geschichte pisze: „Jednakże podczas gdy jeszcze sam Kant zmaga się z psychologicznymi przedstawieniami i insynuacjami, to w jego znaczeniu, zgodnie $\mathrm{z}$ duchem i literą krytycznego systemu, obiektywizujemy rozum w nauce. Krytyka rozumu jest krytyką poznania albo nauki. Krytyka odkrywa to, co czyste w rozumie, jeśli odkrywa ona warunki pewności, na których opiera się poznanie jako nauka"64. W ten sposób otwiera się przed Cohenem nowa perspektywa, która doprowadzi go do radykalnego antypychologizmu, charakterystycznego dla szkoły marburskiej, $\mathrm{w}$ którym to antypsychologizmie fundamentalny stanie się właśnie fakt nauki. $\mathrm{Z}$ tym też wiąże się odmienna od mechanistycznej koncepcja jedności świadomości naukowej. Dzieje się to w roku 1883, a zostaje pogłębione wraz z drugim wydaniem Kants Theorie der Erfahrung w roku 1885.

Kurt Walter Zeidler w kontekście ugruntowania aprioryczności akcentuje jeden ważny fakt, kiedy stwierdza: „Próba czysto naukowologicznego ugruntowania aprioryczności [...] jest umotywowana tym, że dedukcję metafizyczną Kanta rozumie Cohen jako psychologiczną i dla-

\footnotetext{
${ }^{63}$ K. Święcicka, Kantowskie „a priori” w interpretacji Hermanna Cohena, „Archiwum Historii Filozofii i Myśli Społecznej” 1980, t. 26, s. 163.

${ }^{64}$ H. Cohen, Das Princip der Infinitesimal-Methode und seine Geschichte..., dz. cyt., s. 6.
} 
tego też ostatecznie jako empiryczną analizę świadomości”" ${ }^{\prime 65}$. Stąd też w wydaniu Kants Theorie der Erfahrung z roku 1885 pojawia się pojęcie metody transcendentalnej i wokół tego pojęcia, które Cohen wiąże z Newtonem twierdząc, że „metoda transcendentalna powstała jako rezultat namysłu nad Philosophiae naturalis principia mathematica" "66. Przy czym już w Kants Begründung der Ethik Cohen mówi, że metoda transcendentalna jest „nauką o warunkach doświadczenia" ${ }^{67}$. Tym samym ujawnia się tu złożoność myślenia Cohena, co nie przeczy ewolucji wiodącej od psychologizującego ujęcia Kanta do radykalnego antypsychologizmu.

\section{Bibliografia}

Achelis Th., Moritz Lazarus, Book on Demand, Hamburg 1900.

Bratuscheck E., Adolf Trendelenburg, Henschel, Berlin 1873.

Cohen H., Kants Theorie der Erfahrung, t. 2, neubearbeitete Aufl., Dümmlers Verlagsbuchhandlung, Harrwitz und Gossmann, Berlin 1885.

Cohen H., Kants Begründung der Ethik, Dümmler, Berlin 1877.

Cohen H., Kants Theorie der Erfahrung, Dümmler, Berlin 1871.

Cohen H., Die dichterische Phantasie und der Mechanismus des Bewußtseins, „Zeitschrift für Völkerpsychologie und Sprachwissenschaft” 1869, t. 6, F. Dümmler.

Cohen H., Mythologische Vorstellungen von Gott und Seele psychologisch entwickelt II, "Zeitschrift für Völkerpsychologie und Sprachwissenschaft" 1869 , t. 6, F. Dümmler.

Cohen H., Mythologische Vorstellungen von Gott und Seele psychologisch entwickelt, „Zeitschrift für Völkerpsychologie und Sprachwissenschaft” 1868, t. 5, F. Dümmler.

Cohen H., Die platonische Ideenlehre, psychologisch entwickelt, „Zeitschrift für Völkerpsychologie und Sprachwissenschaft" 1866, t. 4, F. Dümmler.

Cohen H., Philosophorum de antinomia necessitatis et contingentia doctrinae, particula I, Hermann, Halae 1865.

Die sprachphilosophischen Werke Wilhelm's von Humboldt, red. H. Steinthal, F. Dümmler, Berlin 1883-1884.

\footnotetext{
${ }^{65}$ K. W. Zeidler, Das Problem der Psychologie im System Cohens (mit Blick auf P. Natorp), [w:] Hermann Cohen und die Erkenntnistheorie, dz. cyt., s. 138.

${ }^{66}$ H. Cohen, Kants Theorie..., s. 67. Por. H. Cohen, Kantowska teoria doświadczenia, tłum. A. J. Noras, Kęty 2012, s. 97.

${ }^{67}$ Tenże, Kants Begründung der Ethik, dz. cyt., s. 18.
} 
Edel G., Winrich de Schmidt: Psychologie und Transzendentalphilosophie, Bonn 1976, „Archiv für Geschichte der Philosophie” 1978, t. 60, Bouvier, s. 236-239.

Eisler R., Wörterbuch der philosophischen Begriffe, 3, Aufl. t. 3, SCI-Z, Berlin 1910, 1678.

Fichte J. G., Reden an die deutsche Nation, [w:] Sämmtliche Werke, red. I. H. Fichte, t. 7, Berlin 1846.

Humboldt W. von, Über die Kawi-Sprache auf der Insel Java, nebst einer Einleitung über die Verschiedenheit des menschlichen Sprachbaues und ihren Einfluss auf die geistige Entwickelung des Menschengeschlechts, t. 3, Druckerei der Königlichen Akademie der Wissenschaften, Berlin 1836-18381839.

Kant I., Krytyka czystego rozumu, t. 2, thum. R. Ingarden, PWN, Warszawa 1957.

Kant I., Kritik der reinen Vernunft (1. Aufl.), [w:] tenże, Gesammelte Schriften, Kritik der reinen Vernunft (1. Aufl.), Prolegomena, Grundlegung zur Metaphysik der Sitten, Metaphysische Anfangsgründe der Naturwissenschaft, t. 4, C.A. Schwetschke und Sohn, Berlin 1903.

Köhnke K. Ch., „Unser junger Freund”. Hermann Cohen und die Völkerpsychologie, [w:] Hermann Cohen und die Erkenntnistheorie, red. W. Marx und E. W. Orth, Königshausen u. Neumann, Würzburg 2001.

Krijnen Ch., Hegel und der Neukantianismus. Eine systemphilosophische Konfrontation, [w:] Hegel und die Geschichte der Philosophie, red. D. H. Heidemann, Ch. Krijnen, Wissenschaftliche Buchgesellschaft, Darmstadt 2007.

Lazarus M., Grundzüge der Völkerpsychologie und Kulturwissenschaft, red. K. Ch. Köhnke, Meiner, Hamburg 2003.

Lazarus M., Einige synthetische Gedanken zur Völkerpsychologie, „Zeitschrift für Völkerpsychologie und Sprachwissenschaft" 1865, t. 3, F. Dümmler.

Lazarus M., Ueber das Verhältniß des Einzelnen zur Gesammtheit, „Zeitschrift für Völkerpsychologie und Sprachwissenschaft" 1862, t. 2, F. Dümmler.

Lazarus M., Verdichtung des Denkens in der Geschichte. Ein Fragment, „Zeitschrift für Völkerpsychologie und Sprachwissenschaft" 1862, t. 2, F. Dümmler.

Lazarus M., Ueber den Begriff und die Möglichkeit einer Völkerpsychologie, „Deutsches Museum. Zeitschrift für Literatur, Kunst und öffentliches Leben" 1851, red. R. Prutz, W. Wolfsohn, rocz. 1. 
Leicht A., Moritz Lazarus (15. September 1824 - 13. April 1903), Mittler, Berlin 1908.

Lembeck K.-H., Platon in Marburg. Platonrezeption und Philosophiegeschichtsphilosophie bei Cohen und Natorp, Königshausen u. Neumann, Würzburg 1994.

Meyer J. B., Kant's Psychologie, Hertz, Berlin 1870.

Natorp P., Allgemeine Psychologie nach kritischer Methode, Mohr, Tübingen 1912.

Natorp P., Einleitung in die Psychologie nach kritischer Methode, Mohr, Freiburg i.B. 1888.

Schmidt W. de, Psychologie und Transzendentalphilosophie. Zur PsychologieRezeption bei Hermann Cohen und Paul Natorp, Bouvier, Bonn 1976.

Sieg U., Aufstieg und Niedergang des Marburger Neukantianismus. Die Geschichte einer philosophischen Schulgemeinschaft, Königshausen u. Neumann, Würzburg 1994.

Steinthal W., Die Sprachwissenschaft Wilh. v. Humboldt's und die Hegel'sche Philosophie, Heymann, Berlin 1848.

\section{Summary}

\section{The Beginnings of Cohen's Philosophy and the Question of Psychology}

Hermann Cohen, the originator of the Neo-Kantian Marburg School, is considered one of the most radical representatives of anti-psychologism. This stance is the result of the process comprised of three integral elements, i.e., the dispute over psychology, the dispute over Plato and the dispute over Kant. As far as the first of them is concerned, Cohen sides with psychologically-inclined linguists, such as Heymann Steinthal and Moritz Lazarus. With regard to the second dispute, Cohen emerges as the interpreter of Plato that he initially theorises in the vein of psychologism, which he later on distances himself from. Finally, as regards the third dispute, this is what determines the eventual critique of the philosophy of Kant.

Keywords: Cohen, Steinthal, Lazarus, Plato, Kant

\section{Zusammenfassung}

\section{Die Anfänge der Philosophie bei Cohen und das Problem der Psychologie}

Hermann Cohen, Begründer der neukantianischen Marburger Schule, gilt als einer der radikalsten Vertreter des Antipsichologismus. Es stellt sich jedoch heraus, dass die Position ein Ergebnis eines Prozesses ist, in dem sich drei Elemente entüllen, und nämlich der Streit über die Psychologie, der über Plato und der über Kant. Im ersten Fall erscheint Cohen mit den psychologisch orientierten Sprachwissenschaftler, Heymann 
Steinthal und Moritz Lazarus, in Verbindung zu bleiben. In zweitem Fall ist Cohen ein Interpret von Plato, wobei anfänglich er seine Philosophie im Geiste des Psychologismus erfasst, um sich später von diesem Standpunkt zu distanzieren. Und daraus geht das spätere Bild der Kants Philosophie hervor.

Schlüsselworte: Cohen, Steinthal, Lazarus, Platon, Kant

Information about Author:

ANDRZEJ J. NORAS, Professor Dr. Habil., Institute of Philosophy, University of Silesia, Poland. Adress for correspondence: ul. Bankowa 11, PL 40-007 Katowice. E-mail: andrzej.noras@us.edu.pl 